\title{
Urban gardening and neglected and underutilized species in Salvador, Bahia, Brazil
}

Manuela Alves da Cunha ${ }^{1 *} \mathbb{D}$, Lidice Almeida Arlego Paraguassú ${ }^{2}$, José Geraldo de Aquino Assis ${ }^{3}$, Arthur Benjamin de Paula Carvalho Silva ${ }^{4}$ and Ryzia de Cassia Vieira Cardoso ${ }^{5}$

\begin{abstract}
Background: Urban agriculture has been evidenced as a food production and environmental sustainability strategy, although it faces many obstacles in Latin American countries. Additionally, in urban areas, low consumption of fruit and greenery is noticeable, along with loss in food diversity, including the neglected and underutilized species (NUS), which involve potential to strengthen local food systems. For this reason, this work has sought to map urban gardens in the city of Salvador, Bahia, Brazil, characterizing their gardeners, and to systematize information regarding food produced and the use of NUS.
\end{abstract}

Methods: The municipality's urban gardens were mapped and data was collected from the gardeners. The study included two steps: (i) garden localization; (ii) on-site visits for interviews with gardeners and verification of cultivated food, destination of production, availability, and use of NUS.

Results: Eighteen active food gardens were located, seventeen of which participated in the study: eight (8) communal (UCG) and nine (9) private (UPG). Respondents were on average 55.76 years old, mostly (52.9\%) male, working at UPG (88.9\%). Women predominated in the UCG (87.5\%), with higher levels of education. For 52.9\% of the interviewees, the garden was their main source of income. Food produced at the urban gardens was consumed by $82.4 \%$ of the gardeners and their families. In $70.6 \%$ of the gardens, production was also sold, while $47.1 \%$ donated. During the survey, 59 NUS were found and $76.5 \%$ of respondents reported consuming 19 of the species. NUS leaves, fruits, and seeds were found to be eaten raw, boiled, or sautéed in various preparations, especially Coleus amboinicus Lour. (76.5\%), Eryngium foetidum L. (35.3\%), Talinum fruticosum (L.) Juss., and Pereskia aculeata Mill (both 29.4\%). Occurrence and utilization of NUS did not present significant associations with the gardens or gardeners $(p>0.05)$.

Conclusions: Salvador urban gardens, even in small numbers and without government support, have produced affordable food for the local population, preserved food diversity, and the tradition of NUS cultivation and use. Thus, urban gardens are reaffirmed as relevant spaces that should be included in public policies in order to promote food and nutritional security, biodiversity, and urban environmental sustainability.

Keywords: Food systems, Urban agriculture, Genetic heritage, Food and nutrition security

\footnotetext{
* Correspondence: manuelanutri@yahoo.com.br

'Escola de Nutrição, Universidade Federal da Bahia, Basílio Gama Street, Canela Campus, Salvador, Bahia 40110-907, Brazil

Full list of author information is available at the end of the article
}

(c) The Author(s). 2020 Open Access This article is licensed under a Creative Commons Attribution 4.0 International License, which permits use, sharing, adaptation, distribution and reproduction in any medium or format, as long as you give appropriate credit to the original author(s) and the source, provide a link to the Creative Commons licence, and indicate if changes were made. The images or other third party material in this article are included in the article's Creative Commons licence, unless indicated otherwise in a credit line to the material. If material is not included in the article's Creative Commons licence and your intended use is not permitted by statutory regulation or exceeds the permitted use, you will need to obtain permission directly from the copyright holder. To view a copy of this licence, visit http://creativecommons.org/licenses/by/4.0/ The Creative Commons Public Domain Dedication waiver (http://creativecommons.org/publicdomain/zero/1.0/) applies to the data made available in this article, unless otherwise stated in a credit line to the data. 


\section{Background}

According to the United Nations, over the next 30 years, the world population is projected to grow by 2 billion people-from the current 7.7 to 9.7 billion in the year 2050 [1]. With increasing urbanization, decreasing arable land, and climate change, it is estimated that agriculture will face major challenges in the future. In addition, by $2030,70 \%$ of the world population is projected to live in cities. Thus, urban agriculture emerges as an alternative to increasing global food production [2].

Worldwide, research has shown that food production through urban agriculture is increasing, with at least 100 million people involved and potential output reaching $50 \mathrm{~kg} / \mathrm{m}^{2}$ annually [2-4]. However, in Latin America and Caribbean cities, this activity has not achieved its full potential and requires greater support from national, unit, and city governments $[5,6]$.

In Brazil, urban agriculture has shown slow development throughout its history, without a specific policy for the promotion and regulation of the activity $[7,8]$. Across the country, urban agriculture initiatives have encountered numerous challenges, including lack of specific legal and policy frameworks, insufficient financial support and technical assistance, difficulties in accessing water of adequate quality, urban land-use restrictions, and lack of legal ownership of the spaces [9].

Parallelly, it is a fact that urbanization and industrialization have brought about several changes in the population's demographic profile, quality of life, and food supply, with consequences on food and nutrition security (FNS) and on the health of individuals [10]. The previously vegetable-based diet has been replaced by high-energy-density alternatives, with soaring levels of sugars and fats, which can cause deleterious effects on human health [11].

In this scenario, the tradition of consuming plant species that have food potential but are not organized in a production chain has been increasingly forgotten [1214]. These vegetables, referred to in Brazil as Plantas Alimentícias Não Convencionais (PANC), are internationally referred to as neglected and underutilized species (NUS) or Especies Olvidadas y Subutilizadas, in Spanish. The terms refer to those species of wild or semi-domesticated plants that are adapted to particular and often local environments that do not receive much attention and are often ignored by researchers, farmers, and lawmakers [15-18].

Neglected and underutilized crops help increase diversification of production and consumption of plant species while providing economic and environmental benefits as farmers can integrate them into crop rotation systems or plant them among other crops, protecting agrobiodiversity [19]. In Brazil, a wide variety of underutilized species may be present in urban flower beds or urban gardens, making contributions from an ecological, economic, nutritional, and cultural perspective. However, many of them suffer pejorative characterization, being classified as "weeds" since they appear in places where they were not cultivated [20].

In the Northeastern Brazilian city of Salvador, Bahia state, urban agriculture is characterized by the presence of urban gardens, which were first recorded during the foundation period of the city, in 1549. The activity continues to the present day and is considered a relevant strategy for local food security, as it provides a larger food supply and encourages the implementation of agroecological practices, in a scenario marked by social inequalities and pockets of poverty. In large part, the activity is developed spontaneously and confronted in its operation, without government support [21-23]. In this sense, research on urban gardens is still insufficient, and there are no systematizations about NUS in these environments.

It should be noted that studies on NUS in Brazilian urban agriculture are still scarce. Therefore, works in this area can contribute to the conservation and valorization of native species, as well as promoting sustainability and healthier eating practices, subsidizing public policies aligned with the food and nutrition security guidelines. Therefore, this research aimed to map urban gardens in the city of Salvador, Bahia, Brazil, characterizing their gardeners in terms of socioeconomic aspects, and to systematize information about the food produced and the use of NUS.

\section{Methods}

A cross-sectional, quantitative study was carried out throughout urban gardens located in the urban area of the municipality of Salvador, Brazil. The study included two steps: (i) mapping of existing urban gardens; (ii) site visits and data collection, with the application of a semistructured questionnaire and verification of food grown, destination of production, availability, and use of NUS in urban gardens. Fieldwork was conducted between September 2018 and May 2019.

The municipality of Salvador is located on the coast of the state of Bahia (between the geographical coordinates $12^{\circ} 59^{\prime} 36.0^{\prime \prime}$ South and $38^{\circ} 31^{\prime} 16.0^{\prime \prime}$ West of Greenwich), constituting the economic, political, and administrative center of the state. The city is the fourth largest capital in Brazil, occupying an area of $693.453 \mathrm{~km}^{2}$. It has an estimated population of 2,886 , 698 inhabitants and a demographic density of 3859.44 inhabitants $/ \mathrm{km}^{2}$. As for the political-administrative organization of the municipality, it comprises 10 administrative regions called neighborhood prefectures and 12 sanitary districts $[24,25]$. 
For the gardens' localization in the urban area of the municipality, initial contacts were made with the Environmental Health Surveillance sector of the Municipal Health Secretariat as well as with community leaders in the sub-municipal political bodies. Information obtained from previous studies with urban gardens in the city was also considered [21-23]. For the geographical location of the gardens, Google Maps was used. In addition, visits to the indicated places were made in order to confirm the existence and functioning of the gardens.

After locating the gardens, site visits were conducted, and the responsible gardeners (manager and main caretaker) were contacted. As inclusion criteria in the study, the gardens that were active, producing vegetables and/ or fruits, and who voluntarily agreed to participate in the research were considered. For the study, private gardens were considered those under the management of a single gardener who may have subordinate workers-in general, the production was mainly intended for commercialization. Community gardens were those that had a gardener in charge (leader) and whose division of labor was shared with other members of the community (volunteers) - the production was mostly intended for subsistence and donation, but could also be marketed.

The managers of the gardens (17 gardeners) answered a semi-structured questionnaire, which included information on socioeconomic aspects (age, marital status, proximity to the garden, education level, family income, working in another profession, and receiving financial benefits from the government); main food grown and destination of production (consumption, donation, and selling); and availability and use of NUS (as food and for medical purposes).

During the visits, the research team, composed of a nutritionist, biologist (botanical specialist), and agronomist, proceeded to walk through the gardens in order to verify the availability of NUS, registering, in a form, the species identified (only the plant species recognized by the researchers were recorded). The plants were also photographed in their natural environment. The scientific and popular names of the plants found were confirmed by consulting a Brazilian guide to identify these species [17], which was developed by researchers of the field and published by Instituto Plantarum - a reference center for research and conservation of Brazilian flora.

This publication is an illustrated identification guide, which provides detailed photographs of these plants, descriptions of their morphological characteristics, and other information such as origin and natural habitat, ways of propagation, parts utilized, and culinary uses. The vouchers of the plants cataloged in this guide are deposited at the Herbarium of the Botanical Garden Plantarum (HPL), in Nova Odessa, São Paulo, Brazil and at the Herbarium of the Federal Institute of Education,
Science and Technology of Amazonas (EAFM), in Manaus, Amazonas, Brazil. Finally, the names of the plant species were checked and updated through consultation with Flora do Brasil 2020 - Botanical Garden, an online system of information on species of the Brazilian flora [26].

Data were tabulated and analyzed by descriptive statistics using the software IBM SPSS version 20 for Windows. Association tests (chi-square) were also applied in order to investigate possible relations between respondents' socioeconomic characteristics, the availability of NUS in the gardens, and consumption by the families. The probability level adopted in the test was 0.05 .

The research project was approved by the Research Ethics Committee of the Federal University of Bahia School of Nutrition (Opinion No. 2.848.192). All research participants signed the informed consent form (ICF), expressing their consent to the conditions of the study and authorizing photographic registration of the plants in their natural place of occurrence.

\section{Results and discussion \\ Mapping of the urban gardens}

Initially, the information collected indicated the existence of 27 active urban gardens, 10 communal (UCG) and 17 private (UPG), distributed in 17 neighborhoods. Considering Salvador's organization in sanitary districts, urban gardens were established in nine of the 12 existing districts. However, it was found that 17 of these gardens were active and with production. In addition, during the visits, one more urban garden was located. Thus, it was possible to identify 18 active gardens ( 8 communal and 10 private), with vegetable and/or fruit production, in the municipality (Fig. 1).

Through the visits to the gardens, it was possible to observe the way in which they are distributed around the urban area of the city (Fig. 2). Since the gardener in charge of one private garden was not found, even after trying to approach him a second time, 17 gardens (8 communal and 9 private) were included in the next stages of the research.

Based on the number of urban gardens identified, there has been a reduction in their quantity in Salvador, Brazil, over the years. In 2013, there were 49 urban gardens in the municipality [21], compared with 18 active urban gardens with food production in 2019-a reduction of $63.3 \%$ in 6 years.

During the visits to the gardens, it was found that some of them, located in public areas, no longer existed, with the area being used for the construction of squares and highways. Although research in different countries has shown that green spaces in residential areas can contribute to food security and the sustainability of urban systems [27-29] and the lack of government support, as 


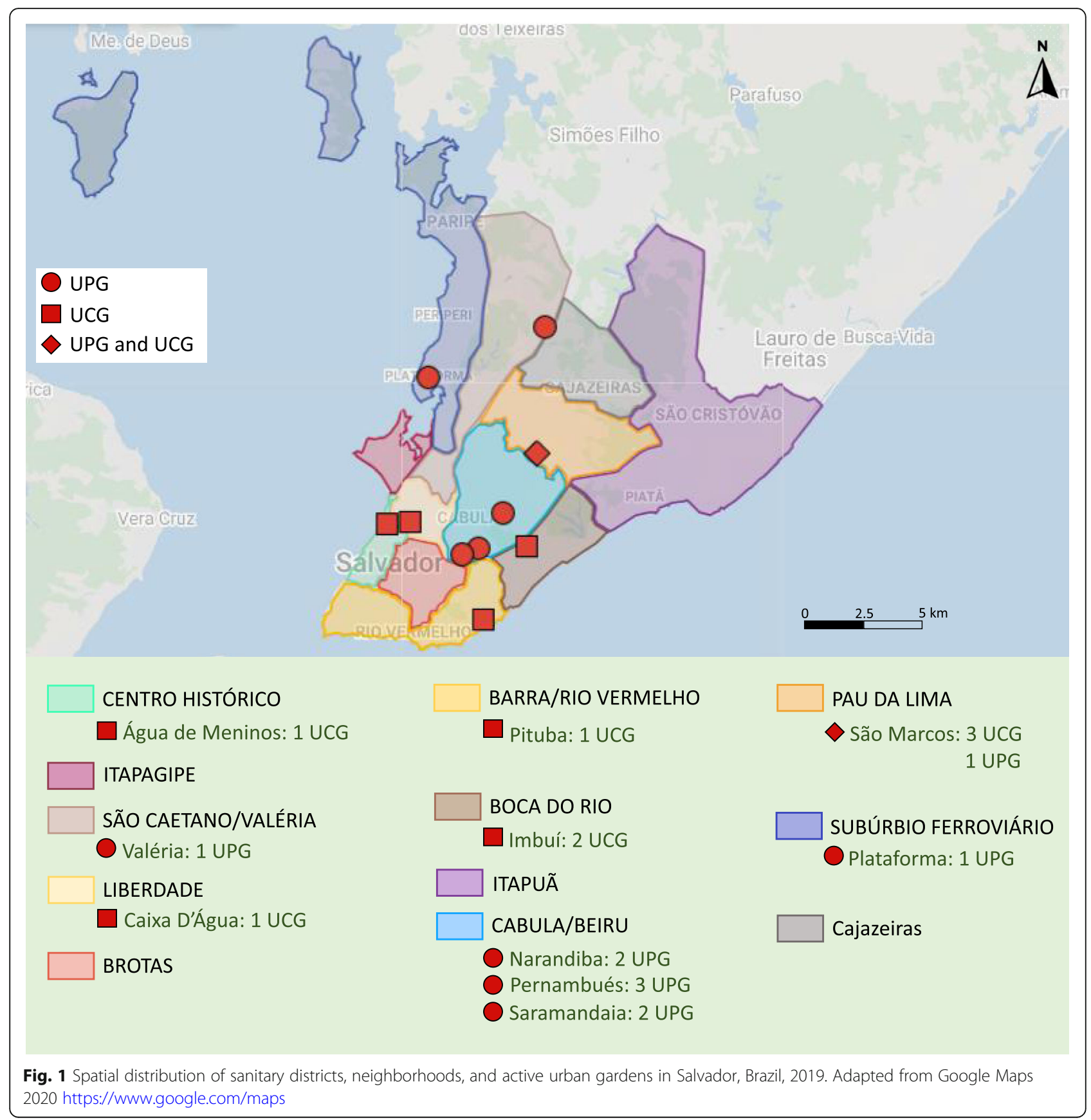

well as the absence of public policies aimed at supply and urban agriculture, can contribute to the decline in municipal agricultural production [5], as also observed in the present study.

Most Brazilian municipalities have no legal framework or legislation that promotes the strengthening of urban agriculture [8, 23], as is the case of Salvador. However, supporting efforts in order to recover and sustain food production sources are important [30, 31]. In Belo Horizonte, Minas Gerais state, the establishment of the Urban Horticulture Support Policy, in which the development of agriculture is guided by a Food Security Council, recognizes the contribution of the activity to the development of the social functions of the municipality [5]. The city of Curitiba, Paraná state, has approved a bill authorizing the occupation of public and private spaces for the development of urban agriculture, seeking to promote sustainable urban production and improve the food security of the population [32].

Cities, when well-managed, can be sources of solutions to the challenges of urbanization [33]. In European cities, in Italy and France, for example, urban gardens are 


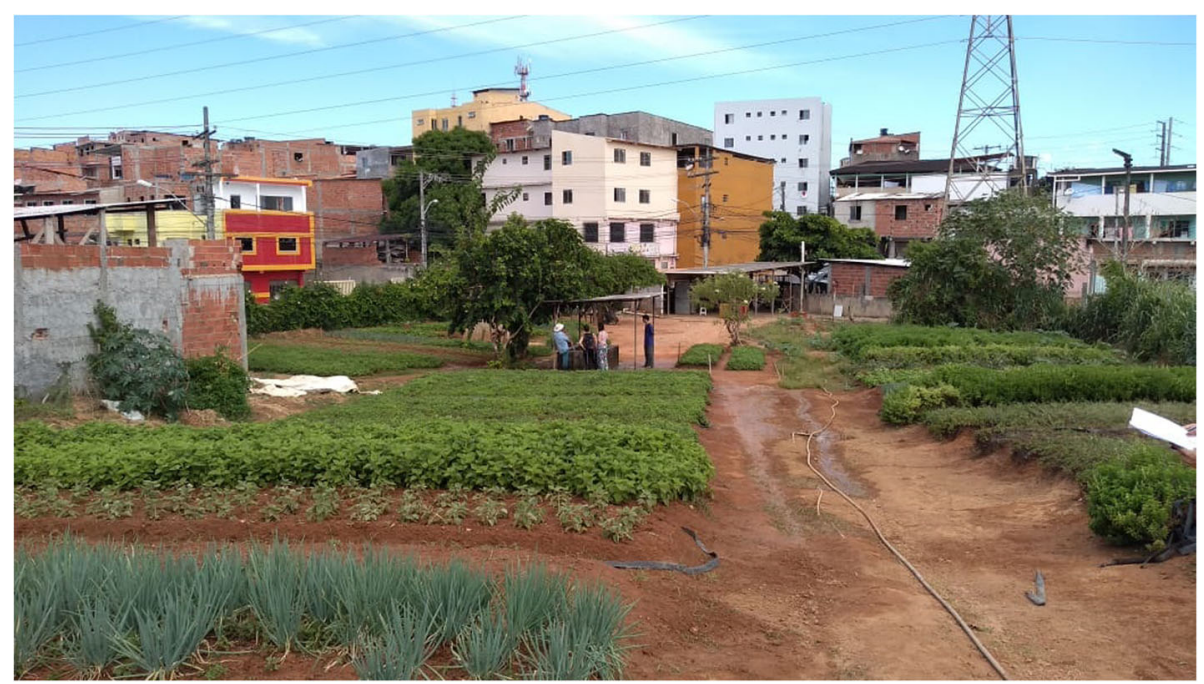

Fig. 2 An urban garden identified in the research in Salvador, Brazil, 2019. Photography from the authors

increasingly popular initiatives [29, 34]. In Paris, France, urban gardens are set up on abandoned land and are managed by associations, which sign a contract with local authorities or landowners, specifying the activities to be carried out and the association's duties, including favoring environmentally sound practices. The initiatives also have the support of the municipality, which also participates in the contract, assuming some responsibilities, such as ensuring the supply of adequate equipment and soil, as well as water supply $[29,35]$.

Socioeconomic aspects of the gardeners Regarding the socioeconomic profile of gardeners responsible for the gardens (Table 1), in Salvador, Brazil, it was found that urban agriculture was mainly developed by older people over the age of fifty, some of them elderly (41.2\%) most of whom were married. The vast majority of respondents (with the exception of one gardener) lived close to gardens, which facilitated the access and conduction of activities, especially for the older ones.

Most of the interviewees were male (mainly in UPG), had a low level of formal education (up to incomplete elementary school), and monthly family income of a maximum of three to four minimum wages. In the UCG, female gardeners predominated, with higher schooling levels and higher monthly family income, reaching more than five minimum wages. However, the majority of UCG respondents had another occupation (merchant, civil servant, traffic engineer, teacher, and researcher) and did not hold the garden as a source of income, carrying out activities on a voluntary basis, as a result of a municipal government initiative that has favored the implementation of community gardens in the city's wealthiest neighborhoods, attracting residents, volunteers, with better socioeconomic conditions [36].

Conversely, most gardeners (seven at UPG and three at UCG) did not have another occupation and most of the interviewees from UPG reported having the gardens as the main source of income, depending on them to guarantee the sustenance of their families. Seven of the respondents said they received retirement or other benefits from the government (Bolsa Família Program), but the minority of them (three gardeners) worked in UPG. In Salvador, less than a third of the total population (29.7\%) has a formal occupation [25]; thus, for many families, informal jobs such as the ones available at urban gardens are a way of ensuring income.

It is clear, therefore, that, in the event of the extinction of these gardens (which has already happened with others mentioned in this study), these families may fall into a situation of food insecurity. A recent study by Souza et al. [37], with urban gardens in Salvador, Brazil, serves as an alert to this problem. The research shows little technical and financial support for urban agriculture and signals the need to formulate policies for the segment, in order to promote better organization, strengthening, and continuity of the activity.

While in Salvador, Brazil, the main motivation for the practice of urban agriculture is income generation, in cities in developed countries, like the USA, France, and Italy, the main reasons for carrying out the activities in gardens is the desire for sustainable green spaces in cities, for healthier food, and for personal well-being (like the pleasure generated by contact with nature) [34, 38, 39]. In a study by Ruggeri et al. [34], some socioeconomic features described about horticulturists in Milan, Italy, resemble the observations in the present study, 
Table 1 Socioeconomic profile of gardeners in charge of urban gardens in Salvador, Brazil, 2019

\begin{tabular}{|c|c|c|c|}
\hline \multirow[t]{2}{*}{ Indicator } & \multicolumn{3}{|l|}{ Distribution } \\
\hline & UCG & UPG & Overall \\
\hline \multicolumn{4}{|l|}{ Age (years) } \\
\hline Range & $31-67$ & $51-66$ & $31-67$ \\
\hline \multirow[t]{2}{*}{ Average (standard deviation) } & $52.50(11.39)$ & $58.67(5.43)$ & $55.76(9.03)$ \\
\hline & $\%(n)$ & $\%(n)$ & $\%(n)$ \\
\hline \multicolumn{4}{|l|}{ Sex } \\
\hline Female & $87.5(7)$ & $11.1(1)$ & $47.1(8)$ \\
\hline Male & $12.5(1)$ & $88.9(8)$ & $52.9(9)$ \\
\hline \multicolumn{4}{|l|}{ Marital status } \\
\hline Single & $37.5(3)$ & $22.2(2)$ & $29.4(5)$ \\
\hline Married & $37.5(3)$ & $44.4(4)$ & $41.2(7)$ \\
\hline Divorced & $25.0(2)$ & $11.1(1)$ & $5.9(1)$ \\
\hline Separated & - & $11.1(1)$ & $17.6(3)$ \\
\hline Widowed & - & - & - \\
\hline Civil partnership & - & $11.1(1)$ & $5.9(1)$ \\
\hline \multicolumn{4}{|l|}{ Resides near garden } \\
\hline Yes & $87.5(7)$ & $100(9)$ & $94.1(16)$ \\
\hline No & $12.5(1)$ & - & $5.9(1)$ \\
\hline \multicolumn{4}{|l|}{ Schooling } \\
\hline Illiterate & - & $22.2(2)$ & $11.8(2)$ \\
\hline Unfinished elementary school & $12.5(1)$ & $77.8(7)$ & $47.1(8)$ \\
\hline Finished elementary school & - & - & - \\
\hline Unfinished high school & - & - & - \\
\hline Finished high school & $25.0(2)$ & - & $11.8(2)$ \\
\hline Unfinished university & $12.5(1)$ & - & $5.9(1)$ \\
\hline Finished university & $50.0(4)$ & - & $23.5(4)$ \\
\hline \multicolumn{4}{|l|}{ Family monthly income ${ }^{a}$} \\
\hline Less than a minimum wage & $14.3(1)$ & $11.1(1)$ & $12.5(2)$ \\
\hline One to two minimum wages & $28.6(2)$ & $77.8(7)$ & $56.3(9)$ \\
\hline Two to three minimum wages & - & - & - \\
\hline Three to four minimum wages & $14.3(1)$ & $11.1(1)$ & $12.5(2)$ \\
\hline Four to five minimum wages & $14.3(1)$ & - & $6.3(1)$ \\
\hline Over five minimum wages & $28.6(2)$ & - & $12.5(2)$ \\
\hline \multicolumn{4}{|l|}{ Other profession } \\
\hline Yes & $50.0(4)$ & $22.2(2)$ & $35.3(6)$ \\
\hline No & $50.0(4)$ & $77.8(7)$ & $64.7(11)$ \\
\hline \multicolumn{4}{|c|}{ Garden is main source of income } \\
\hline Yes & $12.5(1)$ & $88.9(8)$ & $52.9(9)$ \\
\hline No & $25.0(2)$ & $11.1(1)$ & $17.6(3)$ \\
\hline Not applicable & $62.5(5)$ & - & $29.4(5)$ \\
\hline \multicolumn{4}{|l|}{ Financial government benefits ${ }^{a}$} \\
\hline Yes & $57.1(4)$ & $33.3(3)$ & $43.8(7)$ \\
\hline No & 42.9 (3) & $66.7(6)$ & $56.3(9)$ \\
\hline
\end{tabular}

alt was possible to consider only seven UCG 
such as the predominance of male gardeners $(88.0 \%)$, of a more advanced age group (66 years in average). In contrast, the gardeners had a better education level (mostly high school) and a higher monthly income (between 1500 and 2000 euros), when compared with the majority of their counterparts in Salvador, Brazil, and most of them $(87.0 \%)$ were retired, using their free time to develop activities in the gardens.

It is worth mentioning that in the fields "Monthly Family Income" and "Government Financial Benefits", all UPG were included, but seven of the eight UCG were considered. It was not possible to apply these questions to one of them, as it was situated in a community that sheltered homeless people, maintained mainly by donations and with high resident turnover. Thus, these requirements were applied to just sixteen gardens in total.

\section{Cultivated food and destination of production}

The gardeners cited a variety of vegetables and fruits commonly grown in the gardens. Lettuce, mint, chives, cilantro, kale, basil, arugula, okra, cassava, tomato, mango, banana, papaya, avocado, passion fruit, acerola cherry, mombin, orange, guava, and coconut were the main foods cited.

Most of the production was for commercialization, in $70.6 \%$ of the gardens (three UCG and nine UPG), and donation, in $47.1 \%$ of the gardens (five UCG and three UPG), contributing to the municipal food supply. Moreover, food produced in the gardens was consumed by $82.4 \%$ of gardeners and their families. Similarly, in other South American cities, such as Quito, Ecuador, and Lima, Peru, urban agriculture production also is destined for commercialization, consumption, and donation, which contributes to the improvement of food security in the families [5].

Most of the urban gardens in Salvador, Brazil, that donated part of their production (mainly to nursing homes and schools) were community-based. However, the study showed that the quantity of these (five gardens) is still low when compared with other Brazilian cities, such as Belo Horizonte, Minas Gerais, which has 48 community gardens [5], and Teresina, Piauí, with 42 urban gardens [40]. In developed countries, this number may be much higher. In Madison, Wisconsin, USA, about 33.0\% of the households participate in community garden activities, and it is estimated that there are 45,193 of these gardens in the county, providing fresh fruits and vegetables to food insecure populations [27].

In developing countries, urban agriculture can play an important role in FNS, as has been the case in some African countries [41]. In Zimbabwe, 70\% of the population is below the poverty line and, due to the worsening economic situation in the country and food insecurity, the population has adopted different survival strategies, including the intensification of urban agriculture, which has generated a positive impact on families [42]. In the current socio-political and economic scenario in Brazil, where the problem of hunger is once again a matter of concern, the intensification of agricultural practice by urban families could be, as in African countries, a relevant strategy for achieving the human right to healthy eating [43].

\section{Availability and use of NUS}

Among the species of plants grown in urban gardens, few NUS were cited. Nonetheless, during the walk through the gardens, to verify the availability of the plants, a total of fifty-nine NUS were found (Table 2). Images of five species of greater occurrence, photographed in their natural environment, can be seen (Fig. 3).

Neglected and underutilized plant species are described worldwide and their variety is remarkable: 539 vegetables and 645 fruits in Africa, 2800 fruits in the tropics, 200 leafy vegetables in Kenya, 228 vegetables in Southeast Asia, and 137 native vegetables in Italy [44]. In Brazil, there is a wide variety of NUS, with over 3000 species recorded in the literature [17, 45-47].

Studies show that the NUS found in urban gardens in Salvador have the potential for complementing food, perpetuating healthy eating practices, and promoting adequate nutrition. Research with different species of these plants has revealed that they are rich in nutrients, such as proteins, fibers, vitamins, minerals, essential oils, and bioactive compounds with antioxidant capacity, which justifies the stimulus for consumption [17, 48-56].

Although some species of plants found in urban gardens-Coleus amboinicus Lour., Dysphania ambrosioides (L.) Mosyakin \& Clemants, Schinus terebinthifolia Raddi, Cymbopogon citratus (DC.) Stapf, Cucumis anguria L., Curcuma longa L., Spondias purpurea L., Genipa americana L., Eryngium foetidum L.-may be considered NUS in the country, they are traditionally consumed by the population of Bahia, Brazil. Nonetheless, as with most NUS, they are not widely commercialized.

In most community urban gardens studied (five of them), NUS were intended for internal consumption and donation. In contrast, most of the UPG (six gardens) traded NUS (Fig. 4). In this context, three species of NUS-Coleus amboinicus Lour., Eryngium foetidum L. and Cucumis anguria L.-were cultivated, since they are part of the Bahian population's food culture, thus commercialized in the gardens, fairs, or small markets.

Most NUS that grew spontaneously were often uprooted by gardeners, mainly because they had no important commercial value and/or were considered by them as "weeds." The monoculture of a limited number of vegetables and the competitiveness in modern agriculture has been causing the disappearance of NUS, which 
Table 2 NUS in descending order of occurrence in the gardens of Salvador, Brazil, 2019

\begin{tabular}{|c|c|c|c|c|}
\hline \multirow[t]{3}{*}{ Scientific name } & \multirow[t]{3}{*}{ Common names in Brazil } & \multicolumn{3}{|c|}{ Occurrence } \\
\hline & & UCG & UPG & Overall \\
\hline & & $\%(n)$ & $\%(n)$ & $\%(n)$ \\
\hline Talinum fruticosum (L.) Juss. & língua-de-vaca; cariru; beldroega-graúda & $100.0(8)$ & $77.8(7)$ & $88.2(15)$ \\
\hline Amaranthus deflexus $L$. & caruru; caruru-rasteiro; bredo & $50.0(4)$ & $100.0(9)$ & $76.5(13)$ \\
\hline Coleus amboinicus Lour. & hortelã-grosso; hortelã-graúda; hortelã-da-bahia & $100.0(8)$ & $55.6(5)$ & $76.5(13)$ \\
\hline Momordica charantia L. & melão-de-são-caetano; goya; melãozinho & $50.0(4)$ & $88.9(8)$ & $70.6(12)$ \\
\hline Dysphania ambrosioides (L.) Mosyakin \& Clemants & mastruz; erva-de-santa-maria; lombrigueira & $50.0(4)$ & $66.7(6)$ & $58.8(10)$ \\
\hline Portulaca oleracea L. & beldroega; caaponga; porcelana & $62.5(5)$ & $55.6(5)$ & $58.8(10)$ \\
\hline Eryngium foetidum $\mathrm{L}$. & coentro-bravo; coentro-da-índia; coentro-de-caboclo & $37.5(3)$ & $66.7(6)$ & $52.9(9)$ \\
\hline Schinus terebinthifolia Raddi & aroeira; pimenta-rosa; aguaraíba & $62.5(5)$ & $33.3(3)$ & $47.1(8)$ \\
\hline Xanthosoma taioba E. G. Gonç. & taioba; inhame-de-folha; taiá & $62.5(5)$ & $33.3(3)$ & $47.1(8)$ \\
\hline Tripogandra diuretica (Mart.) Handlos & trapoeraba; trapuerava; ondas-do-mar & $50.0(4)$ & $44.4(4)$ & $47.1(8)$ \\
\hline Pereskia aculeata Mill. & ora-pro-nóbis; carne-de-pobre; lobrobó & $75.0(6)$ & $11.1(1)$ & $41.2(7)$ \\
\hline Turnera subulata Sm. & chanana; albina; flor-do-guarujá & $75.0(6)$ & $11.1(1)$ & $41.2(7)$ \\
\hline Cymbopogon citratus (DC.) Stapf & capim-santo; erva-cidreira; capim-limão & $62.5(5)$ & $22.2(2)$ & $41.2(7)$ \\
\hline Cajanus cajan (L.) Huth & andu; guandu; ervilha-do-congo & $87.5(7)$ & - & $41.2(7)$ \\
\hline Peperomia pellucida (L.) Kunth & peperômia; erva-de-jabuti; alfavaca-de-cobra & $25.0(2)$ & $44.4(4)$ & $35.3(6)$ \\
\hline Ocimum campechianum Mill. & alfavaquinha; alfavaca-de-galinha; afavaca-do-mato & $50.0(4)$ & $22.2(2)$ & $35.3(6)$ \\
\hline Cucumis anguria $\mathrm{L}$. & maxixe; maxixo; pepino-espinhoso & $50.0(4)$ & $11.1(1)$ & $29.4(5)$ \\
\hline Moringa oleifera Lam. & moringa; quiabo-de-quina & $50.0(4)$ & - & $23.5(4)$ \\
\hline Solanum stramoniifolium Jacq. & jurubeba; jurubeba-vermelha; jurubeba-do-roçado & $25.0(2)$ & $22.2(2)$ & $23.5(4)$ \\
\hline Sonchus oleraceus L. & serralha; serralheira; chicória-brava & $37.5(3)$ & $11.1(1)$ & $23.5(4)$ \\
\hline Basella alba L. & bertalha; couve-mimosa; espinafre-de-malabar & $25.0(2)$ & $11.1(1)$ & $17.6(3)$ \\
\hline Plantago major $\mathrm{L}$. & tansagem; tanchagem; plantagem & $25.0(2)$ & $11.1(1)$ & $17.6(3)$ \\
\hline Trichosanthes cucumerina $\mathrm{L}$. & quiabo-de-metro; cabaça-cobra; abóbora-jiboia & $12.5(1)$ & $22.2(2)$ & $17.6(3)$ \\
\hline Curcuma longa $\mathrm{L}$. & açafrão-da-terra; açafrão-da-índia; cúrcuma & $37.5(3)$ & - & $17.6(3)$ \\
\hline Solanum americanum Mill. & maria-pretinha; erva-moura; caraxixá & $12.5(1)$ & $22.2(2)$ & $17.6(3)$ \\
\hline Ocimum gratissimum L. & alfavaca-cravo; alfavacão; quioiô & $25.0(2)$ & $11.1(1)$ & $17.6(3)$ \\
\hline Mentha pulegium L. & poejo; hortelãzinho & $25.0(2)$ & - & $11.8(2)$ \\
\hline Hibiscus rosa-sinensis $\mathrm{L}$. & hibisco; graxa-de-estudante; mimo-de-vênus & $12.5(1)$ & $11.1(1)$ & $11.8(2)$ \\
\hline Cnidoscolus aconitifolius (Mill.) I. M. Johnst. & chaya; espinafre-selvagem; urtiga-branca & $25.0(2)$ & - & $11.8(2)$ \\
\hline Piper umbellatum L. & capeba; capeva; aguaxima & $12.5(1)$ & $11.1(1)$ & $11.8(2)$ \\
\hline Boerhavia diffusa $\mathrm{L}$. & pega-pinto; erva-tostão; tangará & $12.5(1)$ & $11.1(1)$ & $11.8(2)$ \\
\hline Oxalis barrelieri $\mathrm{L}$. & azedinha; trevo-arbustivo; trevo-amazônico & $12.5(1)$ & $11.1(1)$ & $11.8(2)$ \\
\hline Boehmeria caudata Sw. & urtiga-mansa; assa-peixe; folha-de-santana & $12.5(1)$ & $11.1(1)$ & $11.8(2)$ \\
\hline Averrhoa bilimbi L. & biri-biri; limão-caieno; bilimbi & $25.0(2)$ & - & $11.8(2)$ \\
\hline Costus amazonicus (Loes.) J. F. Macbr. & cana-de-macaco; cana-do-mato; pobre-velho & $12.5(1)$ & $11.1(1)$ & $11.8(2)$ \\
\hline Bidens pilosa $\mathrm{L}$. & picão-preto; pico-pico; carrapicho-de-agulha & - & $22.2(2)$ & $11.8(2)$ \\
\hline Brassica juncea (L.) Czern. & mostarda; mostarda-verde; mostarda-chinesa & $12.5(1)$ & $11.1(1)$ & $11.8(2)$ \\
\hline Solanum betaceum Cav. & tomatinho-do-mato; tomate-francês; tamarilho; & $25.0(2)$ & - & $11.8(2)$ \\
\hline Spondias purpurea $\mathrm{L}$. & seriguela; cirigueleira; ciriguela & $25.0(2)$ & - & $11.8(2)$ \\
\hline Genipa americana L. & jenipapo; jenipapeiro; jenipapinho & $12.5(1)$ & $11.1(1)$ & $11.8(2)$ \\
\hline Canavalia ensiformis (L.) DC. & feijão-de-porco; feijão-espada & $12.5(1)$ & - & $5.9(1)$ \\
\hline Galinsoga parviflora Cav. & picão-branco; fazendeiro; brinco-de-princesa & $12.5(1)$ & - & $5.9(1)$ \\
\hline
\end{tabular}


Table 2 NUS in descending order of occurrence in the gardens of Salvador, Brazil, 2019 (Continued)

\begin{tabular}{|c|c|c|c|c|}
\hline \multirow[t]{3}{*}{ Scientific name } & \multirow[t]{3}{*}{ Common names in Brazil } & \multicolumn{3}{|c|}{ Occurrence } \\
\hline & & UCG & UPG & Overall \\
\hline & & $\%(n)$ & $\%(n)$ & $\%(n)$ \\
\hline Fridericia chica (Bonpl.) L. G. Lohmann & crajiru; chica; cipó-cruz & $12.5(1)$ & - & $5.9(1)$ \\
\hline Echinodorus macrophyllus (Kunth) Micheli & chapéu-de-couro; chá-de-campanha; erva-do-brejo & $12.5(1)$ & - & $5.9(1)$ \\
\hline Piper peltatum L. & santa-maria; caapeba-amazônica; folha-de-arraia & $12.5(1)$ & - & $5.9(1)$ \\
\hline Physalis pubescens L. & fisális; joá-de-capote; balãozinho & $12.5(1)$ & - & $5.9(1)$ \\
\hline Kalanchoe pinnata (Lam.) Pers. & folha-da-fortuna; corama; pirarucu & $12.5(1)$ & - & $5.9(1)$ \\
\hline Conyza bonariensis (L.) Cronquist & buva; erva-lanceta; voadeira & $12.5(1)$ & - & $5.9(1)$ \\
\hline Terminalia catappa L. & castanhola; sete-copas; chapéu-de-sol & - & $11.1(1)$ & $5.9(1)$ \\
\hline Pteridium aquilinum (L.) Kuhn & samambaia; samambaia-das-taperas; feto & - & $11.1(1)$ & $5.9(1)$ \\
\hline Artocarpus altilis (Parkinson) Fosberg & fruta-pão; fruta-pão-de-massa & - & $11.1(1)$ & $5.9(1)$ \\
\hline Pouteria caimito (Ruiz \& Pav.) Radlk. & abiu; caimito; guapeva & - & $11.1(1)$ & $5.9(1)$ \\
\hline Celosia argentea $\mathrm{L}$. & celosia; espinafre-africano; crista-plumosa & $12.5(1)$ & - & $5.9(1)$ \\
\hline Maranta arundinacea $\mathrm{L}$. & araruta; raruta; maranta & $12.5(1)$ & - & $5.9(1)$ \\
\hline Vigna unguiculata (L.) Walp. & feijão-de-corda; feijão-de-praia; feijão-fradinho & $12.5(1)$ & - & $5.9(1)$ \\
\hline Sicana odorifera (Vell.) Naudin & melão-croá; melão-caboclo; maracujina & $12.5(1)$ & - & $5.9(1)$ \\
\hline Asystasia gangetica (L.) T. Anderson & espinafre-da-índia; coromandel; violeta-chinesa & $12.5(1)$ & - & $5.9(1)$ \\
\hline Hylocereus undatus (Haw.) Britton \& Rose & pitaia; dama-da-noite; pitaia-branca & $12.5(1)$ & - & $5.9(1)$ \\
\hline Syzygium malaccense (L.) Merr. \& L.M. Perry & jambo; jambo-vermelho; jambo-roxo & - & $11.1(1)$ & $5.9(1)$ \\
\hline
\end{tabular}

${ }^{\mathrm{a} U p}$ to three common names were presented for each plant

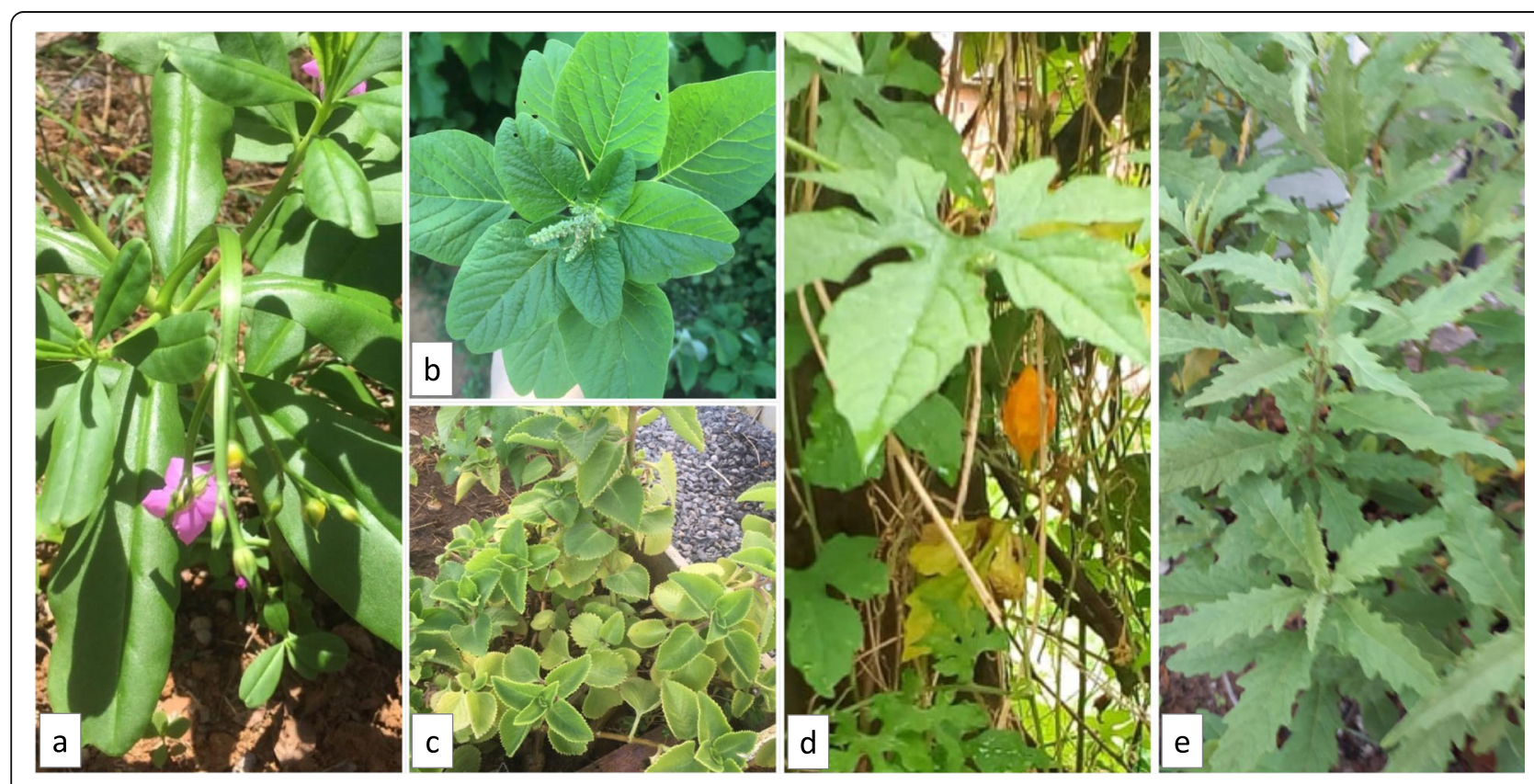

Fig. 3 NUS photographed in urban gardens in Salvador, Brazil, 2019. a Talinum fruticosum (L.) Juss. b Amaranthus deflexus L. c Coleus amboinicus Lour. d Momordica charantia L. e Dysphania ambrosioides (L.) Mosyakin \& Clemants. Photography from the authors 


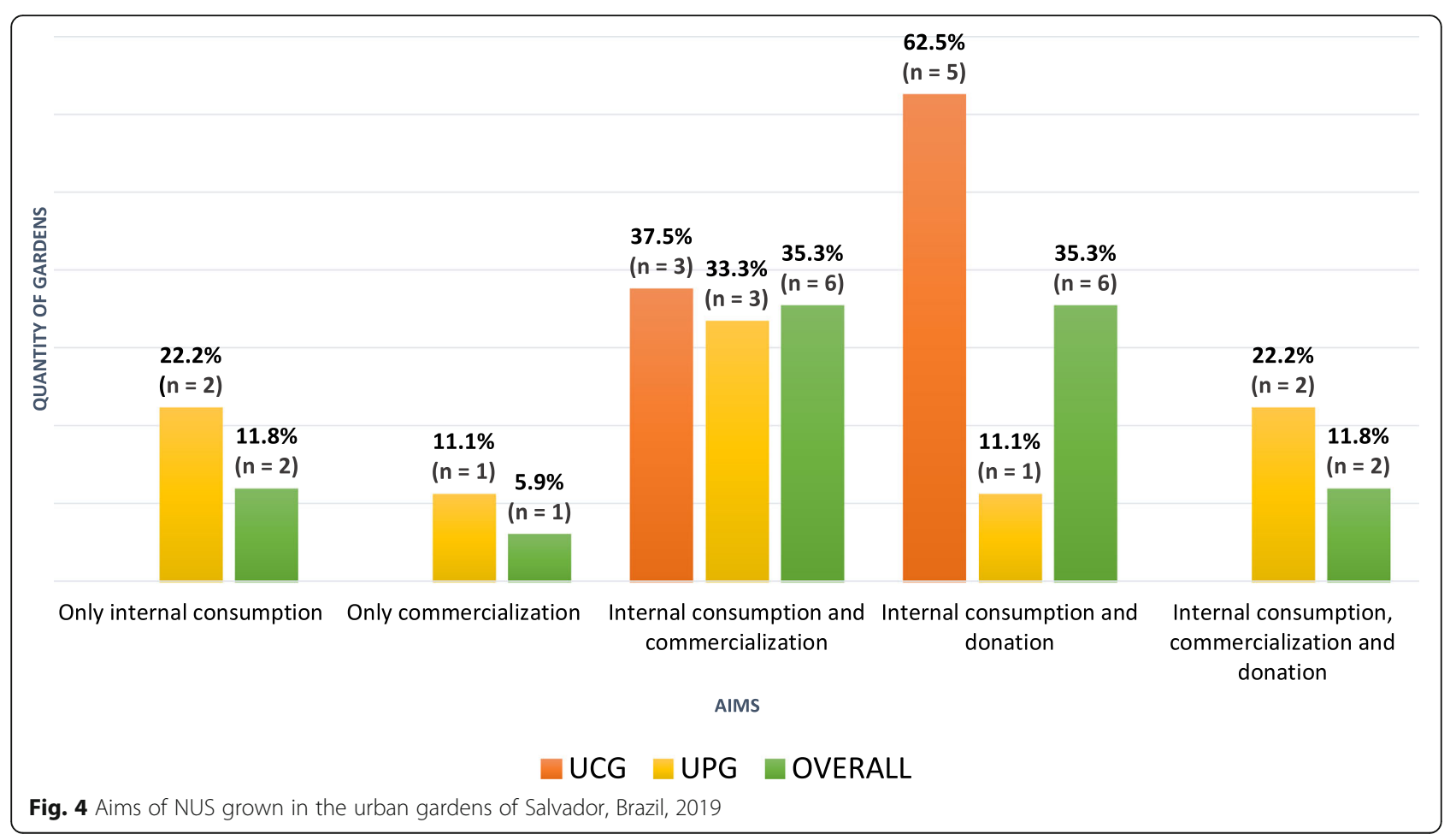

lose space in the global trading circuit, surviving only in small local markets [44]. Besides having potential to improve FNS, cultivation of these plants could promote greater genetic biodiversity, contributing to the maintenance of the ecosystem [13, 57].

Concerning the frequency of NUS consumption by gardeners and their families (Fig. 5), four respondents in charge of UPG reported that their consumption was rare. Although seldom cultivated and spontaneously grown, 76.5\% (all UCG and five UPG respondents) of the gardeners declared using NUS in their family food.

Gardeners reported utilizing nineteen types of NUS to feed their families (Fig. 6).

UPG gardeners (mostly men) reported consuming five species of NUS, while eighteen species of plants were cited by UCG interviewees (women, mostly), which represents $30.5 \%$ of the total NUS found in urban gardens. This finding agrees with the analysis of Padulosi [44], for whom women have been playing an important role in the use of different NUS, promoting the interaction between agrobiodiversity and nutritional security of their families.

Most respondents (70.5\%) also reported using some of the available NUS for medical purposes, including Dysphania ambrosioides (L.) Mosyakin \& Clemants, Plantago major L., Schinus terebinthifolia Raddi, Coleus amboinicus Lour., Moringa oleifera Lam., Solanum stramoniifolium Jacq., Cymbopogon citratus (DC.) Stapf, Eryngium foetidum L., Ocimum gratissimum L., and Solanum americanum Mill. The female respondents also reported using a greater amount of NUS for medicinal purposes, nine of the aforementioned species, while men reported using six of them. Silva et al. [58] carried out a survey on plants used as medicines in rural communities in Piauí, Brazil, and found that women had a fundamental role in the cultivation and use of these vegetables, as well as in the maintenance of having a more specific knowledge of herbs and shrubs used in homemade therapy.

In the present study, it was possible to observe a greater occurrence and a greater use of NUS in UCG, whose respondents were mainly female and had a higher level of education, demonstrating a certain knowledge about the importance of NUS. However, statistical tests performed to verify association between these variables showed no association between occurrence and use of NUS with the type of garden (private or community), nor between the occurrence and use of NUS with the sex or education of gardeners.

As for the main forms of consumption of NUS by the respondents' families (Table 3), the most utilized parts of plants were leaves (68.4\%), with fruits $(26.3 \%)$ and seeds $(5.3 \%)$ in smaller proportion. The species are mostly eaten raw, cooked, or sautéed in various preparations, in the form of juices or used as condiments. In recent years, an increasing number of chefs have been using NUS in their dishes and many have become "gourmet food," mostly eaten by people with higher purchasing power $[14,44]$. However, NUS can contribute to the diversification of menus of families of all socioeconomic 


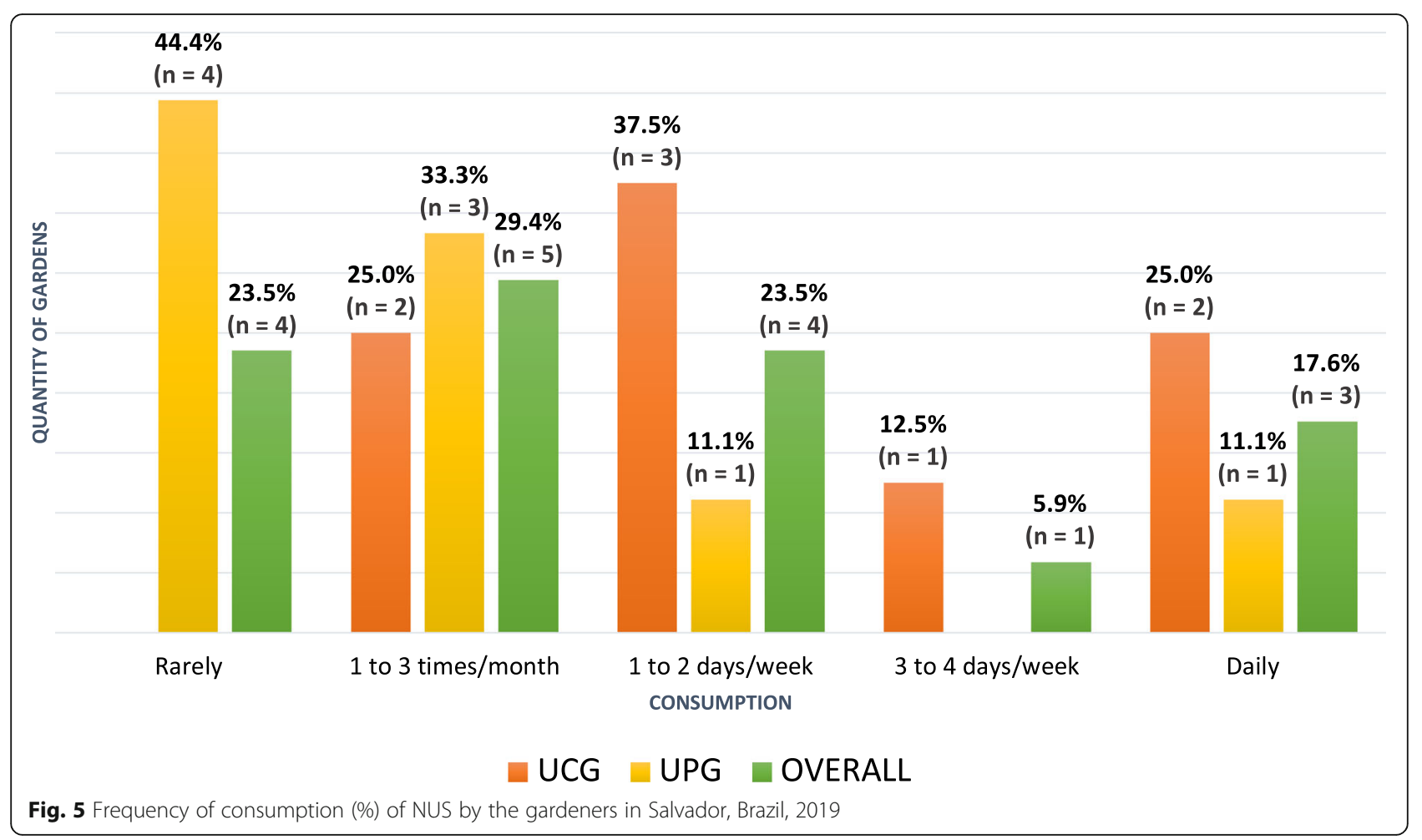

classes. In the present study, a large availability of NUS was found in urban gardens, observing its use in various culinary preparations. This finding confirms the great potential these plants have for food and can be used in a wide variety of dishes.

A similar study investigated the residents' knowledge about NUS in Ribeirão da Ilha, Florianópolis, Santa Catarina state, Brazil [59]. In the research, 63 types of NUS were mentioned and the fruit was the most utilized part, followed by seed, root, leaf, flower, and stalk. The most cited forms of consumption were raw, in juices, alcoholic beverages, sauces, sweets, salads, crumbs, and as food coloring. Other studies that sought to investigate the use of NUS in the feeding of local populations have been carried out in some countries, registering different forms of consumption for these vegetables [12, 60-64].

When asked how they learned to use NUS in their preparations, gardeners reported learning mainly from their parents and/or grandparents, but also from neighbors, teachers, and the internet. Respondents were also asked if the youngest members of their families (children, nephews, grandchildren, etc.) were interested in NUS and $76.5 \%$ said that the youth showed no interest. However, it is not truly possible to valorize the unknown. Learning about the available NUS is essential for the appreciation and conscious use of species. In this sense, the dissemination of scientific knowledge about NUS and its health benefits must be increasingly encouraged [65-67].
Based on the above, the population's food literacy could be considered a strategy to connect individuals, families, and communities to urban gardens, in order to promote a healthy relationship with the available food and engagement in a sustainable food system [68-71]. Research shows that the promotion of food literacy in adults and, most importantly, in children and adolescents, when inserted in the school education process, can generate good results, producing immediate and long-term benefits [71-74].

Although studies that investigate the contributions of NUS to the population's diets are still scarce, research indicates that the consumption of these plants can show contributions. Among them, the reduction of nutritional deficiencies and the offer of local, sustainable, and culturally acceptable solutions to malnutrition problems [14, 16, 75].

In Brazil, $26.5 \%$ of the population lives below the poverty line, and in Bahia, this percentage is above the national average, reaching $44.8 \%$ of the population (6.9 million people). It is a population that is more exposed to disadvantages associated with poverty, such as restrictions on access to services and rights (e.g., basic sanitation and adequate housing) and food insecurity [76]. To face these problems, it is necessary to establish a movement against hegemony, with a focus on promoting agrobiodiversity, and NUS are one of the keys to this. In this sense, the diversification of production systems, with the insertion of NUS, can improve the health of 


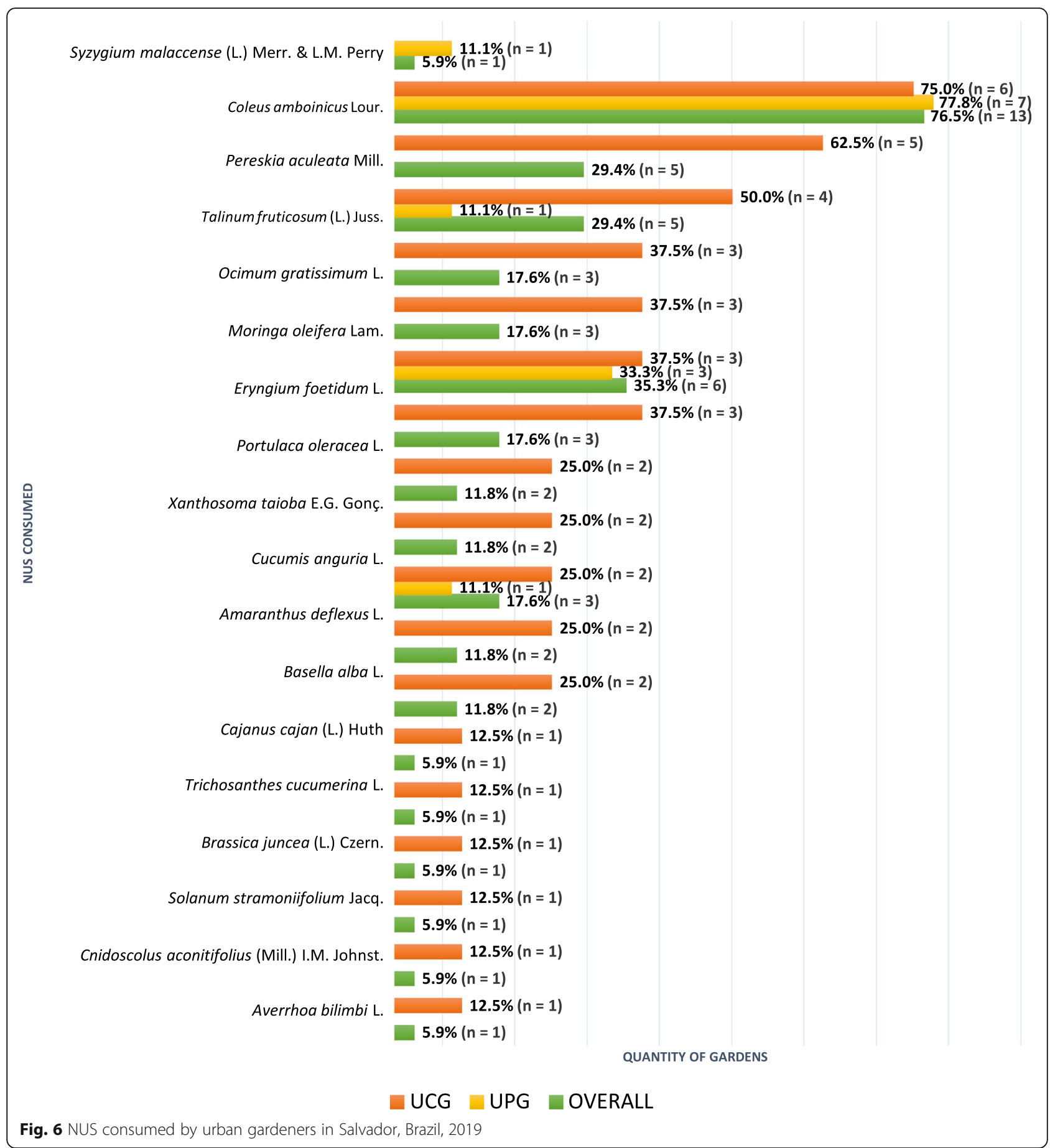

agroecosystems, contribute to protecting food systems, in addition to supporting family farming and promoting food security $[44,75]$.

Therefore, incorporating NUS into national nutrition and FNS policies is an important strategy. Brazilian policies and programs already include the promotion of NUS in dietary guidelines, supporting the production and purchase of these plants for inclusion in school feeding $[14,44]$. Interministerial Ordinance $\mathrm{N}^{\circ}$ 284/
2018, for example, establishes a list of several species of plants of the Brazilian socio-biodiversity, for commercialization purposes, within the scope of operations carried out by the Food Acquisition Program (PAA) [77].

As a challenge, however, most of the urban gardens included in the present research did not work legally. The majority of them (76.5\%) was implanted in a public area, without legal possession of the cultivated spaces and 
Table 3 Forms of NUS consumption by gardeners from urban gardens of Salvador, Brazil, 2019

\begin{tabular}{|c|c|c|c|}
\hline Plant & $\begin{array}{l}\text { Consumed } \\
\text { part }\end{array}$ & Ways to prepare & Preparations \\
\hline \multicolumn{4}{|l|}{ Vegetable/seasoning ${ }^{a}$} \\
\hline Amaranthus deflexus L. & Leaf & Cooked and sautéed & $\begin{array}{l}\text { Cooked with other NUS; cooked with beans or meat; sautéed } \\
\text { with condiments }\end{array}$ \\
\hline Averrhoa bilimbi L. & Leaf & Condiment & Condiment for chicken preparations \\
\hline Basella alba $\mathrm{L}$. & Leaf & $\begin{array}{l}\text { Raw, cooked and } \\
\text { sautéed }\end{array}$ & $\begin{array}{l}\text { Raw and/or cooked salads; omelets; salty pies; soups; sautéed rice; } \\
\text { braised with condiments }\end{array}$ \\
\hline Brassica juncea (L.) Czern & Leaf & Sautéed & $\begin{array}{l}\text { Sautéed with seasonings (similar to the preparation of cauliflower); } \\
\text { sautéed and added in the preparation of farofa }\end{array}$ \\
\hline Cucumis anguria $\mathrm{L}$. & Fruit & Cooked and sautéed & Cooked with meat or chicken; Sautéed with condiments \\
\hline $\begin{array}{l}\text { Cnidoscolus aconitifolius (Mill.) } \\
\text { I.M. Johnst. }\end{array}$ & Leaf & Sautéed & $\begin{array}{l}\text { Sautéed with seasonings (similar to the preparation of cauliflower); } \\
\text { sautéed and added in the preparation of farofa }\end{array}$ \\
\hline Eryngium foetidum $\mathrm{L}$. & Leaf & Condiment & Condiment for the preparation of fish in general and for moqueca \\
\hline Moringa oleifera Lam. & Leaf & Raw, cooked and juice & Raw salad; preparation for cakes and breads; juices and shakes. \\
\hline Ocimum gratissimum L. & Leaf & $\begin{array}{l}\text { Cooked and as } \\
\text { condiment }\end{array}$ & $\begin{array}{l}\text { Cooked with beans; seasoning for the preparation of various recipes } \\
\text { with chicken and meat }\end{array}$ \\
\hline Pereskia aculeata Mill. & Leaf & $\begin{array}{l}\text { Raw, cooked and } \\
\text { sautéed }\end{array}$ & $\begin{array}{l}\text { Raw salads; omelets; cooked with chicken; salty pies; pâté; sautéed } \\
\text { rice; braised with condiments }\end{array}$ \\
\hline Coleus amboinicus Lour. & Leaf & $\begin{array}{l}\text { Raw, juice and as } \\
\text { condiment }\end{array}$ & $\begin{array}{l}\text { Raw salads; green juice; seasoning for the preparation of meat, fish, } \\
\text { and chicken in general and for various preparations such as boiled } \\
\text { chicken and beans }\end{array}$ \\
\hline Portulaca oleracea L. & Leaf & Raw and cooked & Raw salads; cooked with beans or chicken. \\
\hline Schinus terebinthifolia Raddi & Fruit & Condiment & Spice for various dishes (similar to black pepper) \\
\hline Solanum stramoniifolium Jacq. & Fruit & Raw & Raw Salads \\
\hline Talinum fruticosum (L.) Juss. & Leaf & Cooked and sautéed & $\begin{array}{l}\text { Cooked with beans or shrimp and/or pepperoni sausage; sautéed } \\
\text { with seasonings; braised with eggs or shrimps }\end{array}$ \\
\hline Trichosanthes cucumerina $\mathrm{L}$. & Fruit & $\begin{array}{l}\text { Raw, cooked and } \\
\text { sautéed }\end{array}$ & Raw salads; cooked or sautéed with condiments \\
\hline Xanthosoma taioba E.G. Gonç. & Leaf & Cooked and sautéed & As an ingredient in stew; braised with condiments \\
\hline \multicolumn{4}{|l|}{ Legumes $^{a}$} \\
\hline Cajanus cajan (L.) Huth & Seed & Cooked & $\begin{array}{l}\text { Cooked with spices and sometimes with meat (similar to basic bean } \\
\text { preparations) }\end{array}$ \\
\hline \multicolumn{4}{|l|}{ Fruit $^{\mathrm{a}}$} \\
\hline $\begin{array}{l}\text { Syzygium malaccense (L.) Merr. \& } \\
\text { L.M. Perry }\end{array}$ & Fruit & Raw & Consumed in natura, as fruit \\
\hline
\end{tabular}

${ }^{\text {a Food category }}$

none of the respondents was registered as a family farmer, which represents an impediment for supplying food programs such as PAA. In this sense, there are evident gaps in the perspective of public policies aimed at urban agriculture, signaling the need for civil action, decision-making by managers, and investments.

\section{Conclusions}

The study aimed to systematize information about urban gardens, its producers, and the occurrence of NUS in the city of Salvador, Bahia, Brazil, in order to discuss questions regarding supply, healthier eating practices, and sustainability, in line with the national food and nutrition security guidelines.
Based on the gardens' location survey, it was possible to evidence the lack of records in the competent public agencies about urban agriculture in the municipality, which resulted in greater time spent to set the study into operation. A limited number of gardens compared with previous records were identified, which may reflect the lack of government support and incentive to urban agriculture in the municipality. Nevertheless, it was observed that urban, private, and community gardens have contributed to the city's food supply, playing an important role in the population's food and nutrition security and in building a more sustainable urban environment.

Many NUS were available in the city's urban gardens. Most species grew spontaneously and, especially in 
private gardens, were removed as "weeds," favoring the production of high demand foods in the commercialization circuits.

On the other hand, many of the interviewed gardeners, mainly women, have been using some of these vegetables to feed their families. NUS leaves, fruits, and seeds have been cited as ingredients or even as the main element of a large number of culinary preparations, which shows the versatility of the use of these vegetables in the urban population's diet.

In view of the findings, it has been assessed that the formulation of public policies aimed at urban agriculture is essential to support and promote agricultural activities in the municipality of Salvador, Bahia, Brazil, including strategies for the insertion of NUS in the agricultural production and food for the population. In this sense, the integration between Agrobiodiversity and FNS can bring great benefits to the communities of the municipality and to the environment.

In addition, further research is suggested to investigate the nutritional value of NUS, their potential use for menu diversification, strategies for promoting consumption, and their contribution to the health of individuals. Furthermore, there is a need to encourage studies that can strengthen and accompany the development of urban agriculture, in places where the activity is fragile, in view of the local food system.

\section{Abbreviations \\ NUS: Neglected and underutilized species; PANC: Plantas Alimentícias Não Convencionais; FNS: Food and Nutrition Security; UPG: Urban private gardens; UCG: Urban community gardens; HPL: Herbário do Jardim Botânico Plantarum; EAFM: Herbário do Instituto Federal de Educação, Ciência e Tecnologia do Amazonas; PAA: Programa de Aquisição de Alimentos}

\section{Acknowledgements}

We would like to thank the gardeners in charge of the gardens. We thank Marie Agnes Aliaga and Joeli Silva de Souza for accompanying the researchers during the visits to the urban gardens. We also thank the Federal University of Rio Grande do Norte for allowing the researcher Manuela Alves da Cunha to suspend her activities to pursue her doctorate at the Federal University of Bahia.

\section{Authors' contributions}

MAC and RCVC participated in the study design; MAC, LAAP, JGAA, and ABPC carried out visits to the urban gardens and collected data; MAC, RCVC, and JGAA participated in the writing of the article. All authors read and approved the final manuscript.

\section{Authors' information}

MAC: Graduated in Nutrition (Federal University of Rio Grande do Norte UFRN) and Master in Food Science (Federal University of Bahia - UFBA). Adjunct Professor at UFRN and currently undergoing a doctorate in the Program of Post-Graduation in Food, Nutrition and Health (UFBA), studying unconventional food plants. Member of the Research Group in Food Security and Informal Food Trade (Sacia), registered in the National Council for Scientific and Technological Development (CNPq).

LAAP: Graduated in Biology from UFBA and certified Botanical Specialist by the Federal Council of Biology. Master in Sciences, Development, Agriculture, and Society from the Federal Rural University of Rio de Janeiro (UFRRJ) and $\mathrm{PhD}$ in Environment from the University of Salamanca/Spain. Currently a professor at the Federal Institute of Bahia (IFBA) and a biologist at the Environmental Health Surveillance/Salvador City Hall.
JGAA: Graduated in Agronomy from the State University of Bahia (UNEB), Master in Agronomy from São Paulo State University Júlio de Mesquita Filho (UNESP), and PhD in Agronomy from the University of São Paulo (USP). Full professor and researcher at the Biology Institute of UFBA. Current main researches involve neglected and underutilized species.

RCVC: Graduated in Nutrition from UFBA, Master and PhD in Science and Food Technology from Federal University of Viçosa (UFV), and Post-Doctor from the University of London, School of Oriental and African Studies. Full Professor at the UFBA School of Nutrition. Member of the faculty of PostGraduation Programs in Food, Nutrition and Health and Food Science (UFBA). Operates mainly in the following subjects: food security, food informal sector, school meals, and food sanitary surveillance. Leader of the Research Group on Food Security and Informal Food Trade (Sacia), registered within CNPq in 2009.

\section{Funding}

Not applicable.

\section{Availability of data and materials}

The datasets used and/or analyzed during the current study are available from the corresponding author on reasonable request.

\section{Ethics approval and consent to participate}

This research was approved by the Research Ethics Committee of the School of Nutrition of the Federal University of Bahia (Opinion No. 2.848.192). All respondents signed the Free and Informed Consent Form, expressing their consent to the conditions of the study.

\section{Consent for publication}

Not applicable.

\section{Competing interests}

The authors declare that they have no competing interests.

\section{Author details}

${ }^{1}$ Escola de Nutrição, Universidade Federal da Bahia, Basílio Gama Street, Canela Campus, Salvador, Bahia 40110-907, Brazil. ${ }^{2}$ Instituto Federal de Educação, Ciência e Tecnologia da Bahia, Emídio dos Santos Street, Barbalho Campus, Salvador, Bahia 40301-015, Brazil. ${ }^{3}$ Instituto de Biologia,

Universidade Federal da Bahia, 668, Barão de Jeremoabo Street, Ondina Campus, Salvador, Bahia 40170-115, Brazil. ${ }^{4}$ Faculdades Integradas São Pedro - FAESA, 2220, Vitória Avenue, Monte Belo, Vitória, Espírito Santo 29053-360, Brazil. ${ }^{5}$ Escola de Nutrição, Universidade Federal da Bahia, Basílio Gama Street, Canela Campus, Salvador, Bahia 40110-907, Brazil.

Received: 13 April 2020 Accepted: 17 October 2020

Published online: 29 October 2020

\section{References}

1. ONU. Organização das Nações Unidas. População mundial deve chegar a 9,7 bilhões de pessoas em 2050, diz relatório da ONU. 2019. https:// nacoesunidas.org/populacao-mundial-deve-chegar-a-97-bilhoes-de-pessoasem-2050-diz-relatorio-da-onu/. Accessed 25 Aug 2019.

2. Eigenbrod C, Gruda N. Urban vegetable for food security in cities. A review Agronomy for Sustainable Development 2015;35(2):483-498.

3. Wilhelm JA, Smith RG. Ecosystem services and land sparing potential of urban and peri-urban agriculture: a review. Renewable Agriculture Food Syst. 2017;33(5):481-94.

4. Vieira LC, Serrao-Neumann S, Howes M, Mackey B. Unpacking components of sustainable and resilient urban food systems. J Clean Prod. 2018;200:318-30.

5. FAO. Food and Agricultural Organization. Growing greener cities in Latin America and the Caribbean - an FAO report on urban and peri-urban agriculture in the region.2014. http://www.fao.org/3/a-i3696e.pdf. Accessed 29 May 2019.

6. $\quad$ ONU. Organização das Nações Unidas. Mostra de iniciativas de agricultura urbana de pequena escala recebe propostas até 10 de setembro. https:// nacoesunidas.org/mostra-de-iniciativas-de-agricultura-urbana-de-pequenaescala-recebe-propostas-ate-10-de-setembro/. 2017; Accessed 29 May 2019.

7. Vilela SLO, Morais MDC. Agricultura urbana e periurbana: limites e possibilidades de constituição de um sistema agroalimentar localizado 
no município de Teresina - Pl. Revista Econômica do Nordeste 2015; 46(1):97-114.

8. Santana AC, Sequeira GR, Oliveira CM, Gomes SC. Mercado Institucional e Agricultura Urbana e Periurbana em Curuçambá, Ananindeua, Pará: Oportunidades e Desafios. Revista Brasileira de Gestão e Desenvolvimento Regional. 2017;13(1):316-38.

9. Zaar MH. A Agricultura Urbana e Periurbana (AUP) no marco da Soberania Alimentar. Sociedade e Território. 2015;27(3):26-44.

10. Ribeiro SM, Bógus CM, Watanabe HAW. Agricultura urbana agroecológica na perspectiva da promoção da saúde. Saúde e Sociedade. 2015;24(2):730-43.

11. Monteiro CA, Cannon G, Moubarac J, Levy RB, Louzada MLC, Jaime PC. The UN Decade of Nutrition, the NOVA food classification and the trouble with ultra-processing. Public Health Nutr. 2017;21(1):5-17.

12. Rigat $M$, Gras A, D'Ambrosio U, Garnatje T, Parada M, Vallès J. Wild food plants and minor crops in the Ripollès district (Catalonia, Iberian Peninsula): potentialities for developing a local production, consumption and exchange program. J Ethnobiol Ethnomed. 2016;12:49.

13. Meldrum G, Padulosi S, Lochetti G, Robitaille R, Diulgheroff S. Issues and prospects for the sustainable use and conservation of cultivated vegetable diversity for more nutrition-sensitive agriculture. Agriculture. 2018;8(7):112.

14. Hunter D, Borelli T, Beltrame DMO, Oliveira CNS, Coradin L, Wasike WW, Wasilwa L, Mwai J, Manjella A, Samarasinghe GWL, Madhujith T, Nadeeshani HVH, Tan A, Tuğrul Ay S, Güzelsoy N, Lauridsen N, Gee E, Tartanac F. The potential of neglected and underutilized species for improving diets and nutrition. Planta. 2019;250(3):709-29.

15. Padulosi S, Bergamini N, Lawrence T. On farm conservation of neglected and underutilized species: status, trends and novel approaches to cope with climate change. Rome: Bioversity International. 2012. https://www. bioversityinternational.org/fileadmin/_migrated/uploads/tx_news/On-farm_ conservation_of_neglected_and_underutilized_species_status_trends_ and_novel_approaches_to_cope_with_climate_change_1512.pdf. Accessed 31 July 2019.

16. Padulosi, S.; Thompson, J.; Rudebjer, P. Fighting poverty, hunger and malnutrition with neglected and underutilized species: needs, challenges and the way forward. Rome: Bioversity International. 2013. https://cgspace. cgiar.org/handle/10568/68927. Accessed 31 May 2019.

17. Kinupp VF, Lorenzi H. Plantas Alimentícias Não Convencionais (Panc) no Brasil: guia de identificação, aspectos nutricionais e receitas ilustradas. São Paulo: Instituto Plantarum de Estudos da Flora; 2014.

18. Caetano CM, Peña RD, Maigual JL, Vásquez LN, Caetano Nunes D, Pazdiora BRC. Mejoramiento participativo: herramienta para la conservación de cultivos subutilizados y olvidados. Acta Agronómica. 2015;64:307-27.

19. FAO. Food and Agricultural Organization. Promoting neglected and underutilized crop species. 2017; http://www.fao.org/news/story/en/item/1 032516/icode/. Accessed 30 de July 2019.

20. Kelen MEB, Nouhuys ISV, Kehl LCK, Brack P, Silva DB. Plantas Alimentícias Não Convencionais (PANC): hortaliças espontâneas e nativas. 1st ed. Porto Alegre: UFRGS; 2015.

21. LAA P. A agricultura urbana como estratégia de sustentabilidade da cidade do Salvador, Bahia, Brasil [PhD Thesis]. Salamanca, Spain: Universidad de Salamanca; 2013.

22. Mata DMP. Agricultura urbana de produção orgânica: desafios e oportunidades para a formulação de uma política pública na cidade de Salvador [Thesis]. Salvador, Brazil: Universidade Federal da Bahia; 2014.

23. Souza JS. Hortas urbanas comunitárias em Salvador-BA: organização, trabalho e alimentos [Thesis]. Salvador, Brazil: Universidade Federal da Bahia; 2018.

24. Prefeitura Municipal do Salvador. Plano Municipal de Saúde do Salvador: 2018-2021. 2018. http://www.saude.salvador.ba.gov.br/secretaria/wpcontent/uploads/sites/2/2018/12/Plano-Municipal-de-Sa\%C3\%BAde-2018-2 021-VOLUME-I_aprovado-pelo-CMS-21.11.pdf. Accessed 16 Jan 2019.

25. IBGE Instituto Brasileiro de Geografia e Estatística. IBGE/Cidades - Panorama de Salvador https://cidades.ibge.gov.br/brasil/ba/salvador/panorama. Accessed 15 Aug 2020

26. Flora do Brasil - 2020. REFLORA - Plantas do Brasil: Resgate Histórico e Herbário Virtual para o Conhecimento e Conservação da Flora Brasileira. http://floradobrasil.jbrj.gov.br. Accessed 14 Aug 2020

27. Smith VM, Harrington JA. Community food production as food security: resource and economic valuation in Madison, Wisconsin (USA). J Agriculture Food Syst Community Dev. 2014;4(2):61-80.
28. Vila-Ruiz C, Meléndez-Ackerman E, Santiago-Bartolomei R, Garcia-Montiel D, Lastra L, Figuerola CE, Fumero-Caban J. Plant species richness and abundance in residential yards across a tropical watershed: implications for urban sustainability. Ecol Soc. 2014;19(3):22.

29. Torres AC, Nadot S, Prévot A. Specificities of French community gardens as environmental stewardships. Ecol Soc. 2017:22(3):28.

30. Mccubbin SG, Pearce T, Ford JD, Smit B. Social-ecological change and implications for food security in Funafuti. Tuvalu Ecol Soc. 2017;22(1):53.

31. Guilland C, Maron PA, Damas O, Ranjard L. Biodiversity of urban soils for sustainable cities. Environ Chem Lett. 2018;16(4):1267-82.

32. Curitiba. 2018. LEI No 15.300 DE 28 DE SETEMBRO DE 2018. Curitiba, Brazil. https:/leismunicipais.com.br/a/pr/c/curitiba/lei-ordinaria/2018/1530/15300/ lei-ordinaria-n-15300-2018-. Accessed 28 Aug 2019.

33. United Nations. New Urban Agenda. Equador: United Nations. http://habitat3.org/wp-content/uploads/NUA-English.pdf . 2017; Accessed 29 May 2019.

34. Ruggeri G, Mazzocchi C, Corsi S. Urban gardeners' motivations in a metropolitan city: the case of Milan. Sustainability. 2016;8(11):1099.

35. Mairie de Paris. Convention cadre d'occupation et d'usage pour la gestion d'un jardin collectif. https://api-site-cdn.paris.fr/images/123237.pdf. 2012; Accessed 22 July 2019

36. Prefeitura Municipal do Salvador. Secretaria de Comunicação. Horta Urbana Salvador completa um ano com produção de 1,5 mil quilos de alimento. http://www.comunicacao.salvador.ba.gov.br/index.php/todas-asnoticias-4/51047-horta-urbana-salvador-completa-um-ano-com-producaode-1-5-mil-quilos-de-alimento. 2017; Accessed 19 Sept 2019.

37. Souza JS, Cardoso RCV, Paraguassú LAA, Santos SF. The experience of community urban gardens: social organization and food security. Rev Nutr. 2019:32:e180291. https://doi.org/10.1590/1678-9865201932e180291.

38. Clayton S. Domesticated nature: motivations for gardening and perceptions of environmental impact. J Environ Psychol. 2007;27:215-24.

39. Scheromm P. Motivations and practices of gardeners in urban collective gardens: The case of Montpellier. Urban For Urban Green. 2015:14:735-42.

40. Carneiro CT, Da Silva MC, Monteiro ALB, Marinelli NP, Casagrande EF. Iniciativas de hortas comunitárias municipais em Teresina: práticas promotoras de renda e trabalho. Revibec. 2018;28:149-67.

41. Chagomoka T, Drescher A, Glaser R, Marschner B, Schlesinger J, Abizari A, Karg H, Nyandoro G. Urban and peri-urban agriculture and its implication on food and nutrition insecurity in northern Ghana: a socio-spatial analysis along the urban-rural continuum. Popul Environ. 2018;40:27-46.

42. Jongwe A. Synergies between urban agriculture and urban household food security in Gweru City, Zimbabwe. J Dev Agric Econ. 2014;6(2):59-66.

43. FAO - Organización de las Naciones Unidas para la Alimentación y la Agricultura, OPS - Organización Panamericana de la Salud, WFP - Programa Mundial de Alimentos, UNICEF - Fondo de las Naciones Unidas para la Infancia. Panorama de la seguridad alimentaria y nutricional en América Latina y el Caribe 2018. http://www.fao.org/3/CA2127ES/CA2127ES.pdf. 2018; Accessed 13 Aug 2019

44. Padulosi S. Bring NUS back to the table! https://www.bioversityinternational. org/e-library/publications/detail/bring-nus-back-to-the-table/. 2017; Accessed 36 July 2019.

45. Brasil. Ministério da Agricultura, Pecuária e Abastecimento. Secretaria de Desenvolvimento Agropecuário e Cooperativismo. Hortaliças nãoconvencionais (tradicionais). Brasilia: MAPA/ACS; 2010.

46. Kairós I. Guia prático sobre PANC: Plantas Alimentícias Não Convencionais. 1st ed. São Paulo, Instituto Kairós; 2017.

47. Brasil. Ministério do Meio Ambiente. Biodiversidade Brasileira: sabores e aromas. Brasília: MMA; 2018.

48. Silva LFLE, Souza DC, Resende LV, Nassur RDCM, Samartini CQ, Gonçalves WM. Nutritional evaluation of non-conventional vegetables in Brazil. An Acad Bras Cienc. 2018;90(2):1775-87.

49. Uddin M, Juraimi AS, Hossain MS, Un A, Ali M, Rahman MM. Purslane weed (Portulaca oleracea): a prospective plant source of nutrition, omega-3 fatty acid, and antioxidant attributes. Sci World J. 2014:ID951019. https://doi.org/ 10.1155/2014/951019.

50. Venskutonis PR, Kraujalis P. Nutritional components of amaranth seeds and vegetables: a review on composition, properties, and uses. Compr Rev Food Sci Food Saf. 2013;12(4):381-412. 
51. Busani M, Masika PJ, Hugo A, Muchenje V. Nutritional characterization of Moringa (Moringa oleifera Lam.) leaves. Afr J Biotechnol. 2011;10(60): 12925-33.

52. Garcia JA, Corrêa RC, Barros L, Pereira C, Abreu RM, Alves MJ, Calhelha RC, Bracht A, Peralta RM, Ferreira ICFR. Phytochemical profile and biological activities of 'Ora-pro-nobis' leaves (Pereskia aculeata Miller), an underexploited superfood from the Brazilian Atlantic Forest. Food Chem. 2019;294:302-8.

53. Martinevski CS, Oliveira VR, Rios ADO, Flores SH, Venzke JG. Utilização de bertalha (Anredera cordifolia (TEN.) Steenis) e ora-pro-nobis (Pereskia aculeata Mill.) na elaboração de pães. Brazilian J Food Nutr/Alimentos e Nutrição. 2013;24(3):1-6.

54. Sato R, Cilli LPDL, Oliveira BED, Maciel VBV, Venturini AC, Yoshida CMP. Nutritional improvement of pasta with Pereskia aculeata Miller: a non-conventional edible vegetable. Food Science Technology. 2019; 39(Suppl. 1):28-34.

55. Liao DY, Chai YC, Wang SH, Chen CW, Tsai MS. Antioxidant activities and contents of flavonoids and phenolic acids of Talinum triangulare extracts and their immunomodulatory effects. J Food Drug Anal. 2015;23(2):294-302.

56. Oliveira VS, Augusta IM, Braz MVC, Riger CJ, Prudêncio ER, Sawaya ACHF, Sampaio GR, Torres EAFS, Saldanha T. Aroeira fruit (Schinus terebinthifolius Raddi) as a natural antioxidant: chemical constituents, bioactive compounds and in vitro and in vivo antioxidant capacity. Food Chem. 2020;315:126274.

57. Chivenge $P$, Mabhaudhi T, Modi AT, Mafongoya P. The potential role of neglected and underutilised crop species as future crops under water scarce conditions in Sub-Saharan Africa. Int J Environ Res Public Health. 2015;12(6):5685-711

58. Silva MP, Barros RFM, Neto JMM. Farmacopeia natural de comunidades rurais no Estado do Piauí, Nordeste do Brasil. Desenvolvimento e Meio Ambiente. 2015;33:193-207.

59. Leal ML, Alves RP, Hanazaki N. Knowledge, use, and disuse of unconventional food plants. J Ethnobiol Ethnomed. 2018;14:6.

60. Maroyi A. Use of weeds as traditional vegetables in Shurugwi District, Zimbabwe. J Ethnobiol Ethnomed. 2013;9:60.

61. Tebkew M, Gebremariam Y, Mucheye T, Alemu A, Abich A, Fikir D. Uses of wild edible plants in Quara district, northwest Ethiopia: implication for forest management. Agriculture Food Security. 2018;7:12.

62. Ojelel S, Mucunguzi P, Katuura E, Kakudidi EK, Namaganda M, Kalema J. Wild edible plants used by communities in and around selected forest reserves of Teso-Karamoja region, Uganda. J Ethnobiol Ethnomed. 2019;15:3.

63. Yeşil Y, Çelik M, Yılmaz B. Wild edible plants in Yeşilli (Mardin-Turkey), a multicultural area. J Ethnobiol Ethnomed. 2019;15:52.

64. Wang J, Seyler BC, Ticktin T, Zeng Y, Ayu K. An ethnobotanical survey of wild edible plants used by the Yi people of Liangshan Prefecture, Sichuan Province, China. J Ethnobiol Ethnomed. 2020;16:10.

65. Cruz MP, Peroni N, Albuquerque UP. Knowledge, use and management of native wild edible plants from a seasonal dry forest (NE, Brazil). J Ethnobio Ethnomed. 2013;9:79.

66. Borges CKGD, Silva CC. Plantas alimentícias não convencionais (PANC): a divulgação científica das espécies na cidade de Manaus. AM Revista Eletrônica Científica Ensino Interdisciplinar. 2018;4(11):466-77.

67. Jacob MCM. Biodiversity of underutilized food plants in a community-based learning garden. Demetra. 2020;15:e43568. https://doi.org/10.12957/ demetra.2020.44037.

68. Grubb M, Vogl CR. Understanding food literacy in urban gardeners: a case study of the Twin Cities. Minnesota Sustainability. 2019;11(13):3617.

69. Vidgen HA, Gallegos D. Defining food literacy and its components. Appetite. 2014;76:50-9.

70. Perry EA, Thomas H, Samra HR, Edmonstone S, Davidson L, Faulkner A Petermann L, Manafò E, Kirkpatrick SI. Identifying attributes of food literacy: a scoping review. Public Health Nutr. 2017;20(13):2406-15.

71. Begley A, Paynter E, Butcher L, Bobongie V, Dhaliwal SS. Identifying who improves or maintains their food literacy behaviours after completing an adult program. Int J Environ Res Public Health. 2020;17(12):4462.

72. Begley A, Paynter E, Butcher LM, Dhaliwal SS. Effectiveness of an adult food literacy program. Nutrients. 2019;11(4):797.

73. Nanayakkara J, Margerison C, Worsley A. Senior secondary school food literacy education: importance, challenges, and ways of improving. Nutrients. 2018;10(9):1316.

74. Velardo S, Drummond M. Qualitative insight into primary school children's nutrition literacy. Health Educ. 2019;119(2):98-114.
75. Campanaro A, Tommasi N, Guzzetti L, Galimberti A, Bruni I, Labra M. DNA barcoding to promote social awareness and identity of neglected, underutilized plant species having valuable nutritional properties. Food Res Int. 2019;115:1-9.

76. IBGE. Instituto Brasileiro de Geografia e Estatística. Síntese de Indicadores Sociais: uma análise das condições de vida da população brasileira. Rio de Janeiro: IBGE; 2018.

77. Brasil. 2018. Ministério do Meio Ambiente. PORTARIA INTERMINISTERIAL Nº 284 DE 30 DE MAIO DE 2018. http://www.in.gov.br/materia/-/asset_publisher/ Kujrw0TZC2Mb/content/id/29306868/do1-2018-07-10-portaria-interministerialn-284-de-30-de-maio-de-2018-29306860. Accessed 01 Out 2019.

\section{Publisher's Note}

Springer Nature remains neutral with regard to jurisdictional claims in published maps and institutional affiliations.
Ready to submit your research? Choose BMC and benefit from:

- fast, convenient online submission

- thorough peer review by experienced researchers in your field

- rapid publication on acceptance

- support for research data, including large and complex data types

- gold Open Access which fosters wider collaboration and increased citations

- maximum visibility for your research: over $100 \mathrm{M}$ website views per year

At BMC, research is always in progress.

Learn more biomedcentral.com/submissions 